\title{
Growth-Inhibitory Activity of Melatonin on Human Androgen-Independent DU I 45 Prostate Cancer Cells
}

\author{
M. Montagnani Marelli, P. Limonta, R. Maggi, M. Motta, and R.M. Moretti* \\ Center for Endocrinological Oncology, University of Milan, Milan, Italy
}

\begin{abstract}
BACKGROUND. The pineal hormone melatonin has been shown to exert a direct oncostatic activity on neoplastic cells, particularly from breast cancer. In the present study, we evaluated the effects of melatonin on the proliferation and on the cell cycle distribution of human androgen-independent DU 145 prostate cancer cells. Experiments were also performed to gain insights into the possible mechanism of action of the hormone.

METHODS. The effects of melatonin on DU 145 cell proliferation was analyzed by counting the cells by hemocytometer at the end of treatment. The effects of the pineal hormone on cell cycle distribution were evaluated by FACS analysis. RT-PCR studies were performed to detect $\mathrm{Mel}_{1 \mathrm{a}}$ and $\mathrm{Mel}_{1 \mathrm{~b}}$ expression in DU 145 cells. The cellular localization of ${ }^{125} \mathrm{I}$-melatonin binding sites was investigated by radioreceptor assay. A commercially available binding-protein assay kit was utilized to evaluate intracellular cAMP levels.

RESULTS. Melatonin, in physiological doses, significantly inhibited DU 145 cell proliferation and induced cell cycle withdrawal by accumulating cells in G0/G1 phase. The mRNA for $\mathrm{Mel}_{1 \mathrm{a}}$ receptors was found to be expressed in DU 145 cells; however, by radioreceptor assay, no binding sites for ${ }^{125} \mathrm{I}$-melatonin could be detected in membrane preparations, suggesting that, in these cells, the level of translation of this mRNA is too low to possibly mediate the antiproliferative action of the hormone. In agreement with this hypothesis, melatonin did not affect forskolin-induced intracellular cAMP accumulation. Binding sites for ${ }^{125} \mathrm{I}$-melatonin were found in nuclear extracts of DU 145 cells.

CONCLUSIONS. Melatonin exerts a direct oncostatic activity on human androgenindependent prostate cancer cells, by affecting cell cycle progression. This activity seems to be mediated by nuclear, but not by membrane, receptors. Prostate 45:238-244, 2000.
\end{abstract}

(c) 2000 Wiley-Liss, Inc.

KEY WORDS: $\quad$ melatonin; prostate cancer; cell cycle; receptors; DU 145

\section{INTRODUCTION}

Melatonin, the indolic hormone produced by the pineal gland, is known to participate in the control of many physiological processes, including circadian rhythms, sexual reproduction, aging, and immune function [1]. During the last few years, experimental evidence has been accumulating, to indicate a link between melatonin and the growth of neoplastic tissues [2]. Modulation of pineal gland function has been shown to affect tumor growth in experimentally induced breast cancer [3]; moreover, nocturnal secretion of melatonin is reduced in a number of human malignancies [4-6]. Although these effects might be related to either the free radical scavenging or immunostim- ulatory activity of the hormone, several reports in the literature strongly support the hypothesis that melatonin might also exert a direct antiproliferative action at the level of the tumor tissue, particularly of breast cancer $[7,8]$.

In a recent paper, we showed that melatonin sig-

Grant sponsor: Associazione Italiana per la Ricerca sul Cancro; Grant sponsor: Ministero dell'Università e della Ricerca Scientifica e Tecnologica.

${ }^{*}$ Correspondence to: Dr. R.M. Moretti, Center for Endocrinological Oncology, University of Milan, Via Balzaretti 9, 20133 Milan, Italy. E-mail: roberta.moretti@unimi.it

Received 29 February 2000; Accepted 30 May 2000 
nificantly inhibits the growth of the human androgensensitive LNCaP prostate cancer cell line [9]. It is well known that prostate carcinoma, which is usually androgen-dependent in its early phases, very often progresses to a condition in which the androgen dependence is lost [10]. While androgen withdrawal represents the most common and successful therapy for the pathology in its early stages [11], the therapeutic options for the more advanced, steroid-resistant prostate carcinoma are still very limited [10]. In the present study, we analyzed the effects of melatonin on: 1) the proliferation, and 2) the cell cycle distribution of human androgen-independent (DU 145) prostate cancer cells. Experiments were also performed to gain insights into the possible mechanism of action of the hormone, since the molecular mechanisms underlying the oncostatic activity of melatonin are still a matter of debate.

\section{MATERIALS AND METHODS}

\section{Materials}

Melatonin was purchased from Sigma Chemical Co. (St. Louis, MO); 2-[ $\left.{ }^{125} \mathrm{I}\right]$ iodomelatonin was obtained from NEN-Life Science Products (Milan, Italy).

\section{Cell Culture}

The cell line DU 145 was obtained from the American Type Culture Collection (Rockville, MD). These cells were derived from a brain metastasis of a human androgen-unresponsive prostate carcinoma; they retain the androgen independence of the original tumor and do not express the androgen receptor [12]. DU 145 cells (passages 60-70) were routinely grown in RPMI1640 medium (Seromed Biochrom, Berlin, Germany) supplemented with 5\% fetal bovine serum (FBS, Life Technologies, Paisley, Scotland, UK), glutamine (1 $\mathrm{mmol} / \mathrm{l})$, and antibiotics $(100 \mathrm{U} / \mathrm{ml}$ penicillin $\mathrm{G}$ sodium and $100 \mu \mathrm{g} / \mathrm{ml}$ streptomycin sulfate) in a humidified atmosphere of $5 \% \mathrm{CO}_{2}-95 \%$ air. Under these conditions, the doubling time was $36 \mathrm{hr}$.

\section{Cell Proliferation Studies}

Cell growth studies were performed on exponentially growing cells. DU 145 cells were plated at a density of 300 cells $/ \mathrm{cm}^{2}$ in $100-\mathrm{mm}$ dishes. Treatment started 2 days after plating. Cells were treated every day with melatonin (0.01-100 nM) for 7 days. At the end of treatment, cells were harvested and counted by hemocytometer.

\section{FACS Analysis}

Fluorescence-activated cell sorting (FACS) analysis was performed as described [13]. DU 145 cells were plated at a density of 4,000 cells $/ \mathrm{cm}^{2}$ in $100-\mathrm{mm}$ dishes in RPMI-1640 supplemented with 5\% FBS. Twenty-four hours after plating, cells were treated either with vehicle or with melatonin $(0.01,1$, and 100 $\mathrm{nM})$ for $48 \mathrm{hr}$. After treatment, DU 145 cells were trypsinized, washed twice with ice-cold PBS, fixed by dropwise addition of $70 \%$ ethanol, and incubated at $4^{\circ} \mathrm{C}$ overnight with constant agitation. Thirty minutes before flow cytometric analysis, the cellular doublestranded nucleic acids were stained with propidium iodine $(50 \mu \mathrm{g} / \mathrm{ml})$. RNAse (100 units $/ \mathrm{ml})$ was included to degrade double-stranded RNA. Propidium iodine fluorescence was obtained using linear amplification with doublet discrimination. Five thousand forward scatter-gated events were collected per sample. Data were analyzed by the Cellquest program (Becton Dickinson, San Jose, CA).

\section{Mel $_{\mathrm{la}}$ and $\mathrm{Mel}_{\mathrm{Ib}}$ Expression by RT-PCR}

In order to determine whether membrane $\left(\mathrm{Mel}_{1 \mathrm{a}}\right.$ and $\mathrm{Mel}_{1 \mathrm{~b}}$ ) receptors are expressed in prostate cancer cells, RT-PCR was performed on RNA extracts from DU 145 cells and HEK293 (positive control). After phenol-chloroform extraction, $1 \mu \mathrm{g}$ of total RNA from each sample was used in a reverse transcription reaction. cDNA synthesis was performed using the Gene AMP kit (Perkin Elmer Cetus, Norwalk, CT), with an oligo(dT $)_{16}$ as a primer for the reverse transcriptase. Samples containing cDNAs obtained from cells were then amplified in a 100- $\mu$ l solution containing PCR buffer (50 mM KCl, $10 \mathrm{mM}$ Tris- $\mathrm{HCl}$ ), $2 \mathrm{mM} \mathrm{MgCl}$, 100 pmoles of a pair of specific primers, and 2.5 U Taq Polymerase. Thirty-five cycles of amplification were performed in a programmable heat block (Perkin Elmer Cetus) (90 sec denaturation at $94^{\circ} \mathrm{C}, 90 \mathrm{sec}$ primer annealing at $54^{\circ} \mathrm{C}$, and 2 min primer extension at $72^{\circ} \mathrm{C}$ ). The primers were: $5^{\prime}$-CTGGCCTGCGTCCTCATCTTCACCATCGTG-3' (sense, 88-117) and 5'CCATGCTGGCGGGGTCAGAGGC-3' (antisense, 784-805) for $\mathrm{Mel}_{1 \mathrm{a}}$ [14], and 5'-CGCTGTCCGCGGTGCTCATCGTCACCACC-3' (sense, 125-153) and 5'CCAGGGCCCAGCCGTCATAGAAGATG-3' (antisense, 300-325) for $\mathrm{Mel}_{1 \mathrm{~b}}$ [14]. After RT-PCR, the amplified DNA products were separated on a $1.5 \%$ agarose gel and stained with ethidium bromide. Southern blotting analysis was performed, and blots were hybridized with synthetic ${ }^{32} \mathrm{P}$-labeled oligonucleotide probes: 5'-TGCGTTCCTGAGCTTCTTGTTCCGATACAC-3' (154-183) for $\mathrm{Mel}_{1 \mathrm{a}}$ [14], and 5'- 
TGCGTTCCGGAGCTTGCGGTTCCTGAGCAC-3' (193-222) for $\mathrm{Mel}_{1 \mathrm{~b}}$ [14].

\section{Melatonin-Binding Studies}

Experiments were performed to clarify the cellular (nuclear vs. membrane) localization of melatonin binding sites in prostate cancer cells. To this purpose, nuclear and membrane preparations were obtained from DU 145 cells as previously described [15], with slight modifications. Briefly, cells were harvested with PBS and centrifuged at $4,000 \mathrm{~g}$ for $10 \mathrm{~min}$. Cell pellets were resuspended in sucrose $0.32 \mathrm{M}$, homogenized with an Ultra-turrax homogenizer, and then centrifuged at $800 \mathrm{~g}$ for $10 \mathrm{~min}$ at $4^{\circ} \mathrm{C}$. The nuclear pellets were gently resuspended in $10 \mathrm{mM}$ Tris- $\mathrm{HCl} /$ Triton X-100 0.1\% (pH 7.6). The resulting supernatants, containing the membranes, were then centrifuged at $48,000 \mathrm{~g}$ for $30 \mathrm{~min}$ at $4^{\circ} \mathrm{C}$. The membrane pellets were washed and resuspended in $10 \mathrm{mM}$ Tris- $\mathrm{HCl}$ buffer. Melatonin binding assays were performed as described [16], combining both saturation and displacement protocols in the same curve. By effectively combining both saturation and competition protocols in the same curve, one can reach high concentrations of ligand without consuming excessive amounts of labeled ligand (competition part of the curve), yet have adequate radioactivity in the lower concentration range (saturation part of the curve). The saturation part of the curve was performed by incubating membrane or nuclear preparations $(100 \mu \mathrm{l})$ with $2-\left[{ }^{125} \mathrm{I}\right] \mathrm{io}-$ domelatonin $\left(5 \times 10^{-13}-10^{-9} \mathrm{M}, 100 \mu \mathrm{l}\right)$ in a total volume of $300 \mu$ l. The competition part of the curve was performed by incubating membrane or nuclear preparations $(100 \mu \mathrm{l})$ with $\left.2-{ }^{125} \mathrm{I}\right]$ iodomelatonin $\left(10^{-9} \mathrm{M}\right.$, $100 \mu \mathrm{l})$ in the presence of unlabeled melatonin $\left(10^{-9}\right.$ $10^{-6} \mathrm{M}, 100 \mu \mathrm{l}$ ) in a total volume of $300 \mu \mathrm{l}$. After $2 \mathrm{hr}$ incubation at room temperature, $1 \mathrm{ml}$ ice-cold assay buffer was added, and the tubes were immediately centrifuged at $48,000 \mathrm{~g}$ for $30 \mathrm{~min}$ for membranes, and at $800 \mathrm{~g}$ for $10 \mathrm{~min}$ for nuclear preparations. Supernatants were discarded and pellets were counted in a $\gamma$-counter. Simultaneous analysis of the data from the saturation and competition protocols for the same curves was performed by the Ligand program [17]. The protein content of each membrane or nuclear preparation was evaluated according to the method of Bradford [18].

\section{cAMP Assay}

Intracellular cyclic AMP accumulation was measured over a 15-min incubation period of subconfluent DU 145 cells, with $5 \mu \mathrm{M}$ forskolin (Sigma Chemical Co.) as activator of adenylcyclase in the absence or in

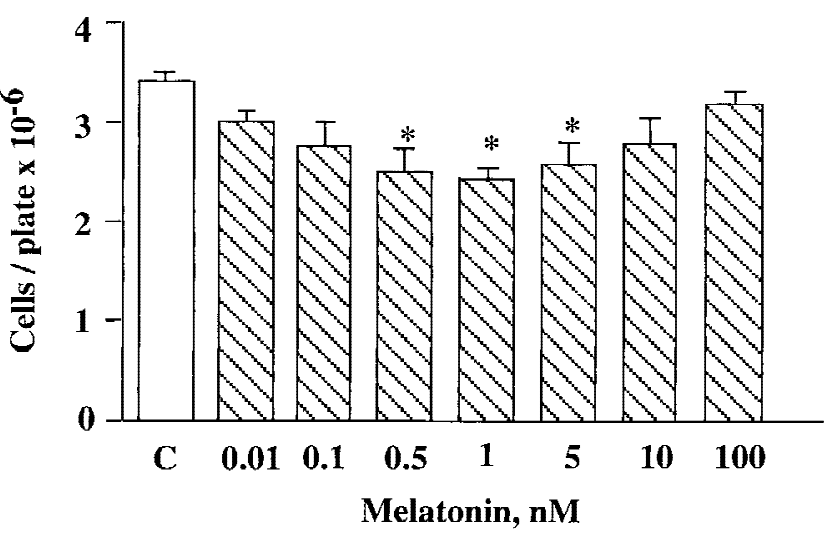

Fig. I. Effects of melatonin on the proliferation of DU I 45 cells. Results are expressed as mean cell number per plate \pm SE. Results are representative of four separate experiments. C, controls without melatonin. $* P<0.05$ vs. $C$.

the presence of melatonin ( $1 \mathrm{nM})$, after a 15-min preincubation with the phosphodiesterase inhibitor 3-isobutyl-1-methil-xantine $(0.5 \mathrm{mM})$ (Sigma Chemical Co.). A commercially available binding-protein assay kit (Amersham, Milan, Italy) was used to evaluate cAMP levels in ethanol extracted cells, according to the manufacturer's instructions.

\section{Statistical Analysis}

The data from experiments involving cell proliferation and cAMP formation were analyzed according to the test of Dunnett [19], after one-way analysis of variance.

\section{RESULTS}

\section{Effects of Melatonin on Cell Proliferation}

The effects of treatment with melatonin (0.01-100 $\mathrm{nM})$ on DU 145 cell growth are reported in Figure 1. In DU 145 cells, melatonin significantly inhibited cell proliferation when utilized in nanomolar concentrations $(0.5-5 \mathrm{nM})$. Lower $(0.01$ and $0.1 \mathrm{nM})$ or higher $(10$ and $100 \mathrm{nM}$ ) doses of the hormone were found to be ineffective (Fig. 1).

\section{Effects of Melatonin on Cell Cycle Distribution}

To analyze in more detail the antiproliferative action of melatonin on DU 145 cells, we evaluated the possible effect of the hormone in the control of cell cycle progression. By FACS scan analysis, we showed that treatment with melatonin $(1 \mathrm{nM})$ caused a significant accumulation of cells in G0/G1 phase and a decrease in the $S$ phase of the cell cycle (Table I). A lower 


\begin{tabular}{lcccc}
\hline TABLE I. Effects of Melatonin on Cell Cycle Distribution \\
of DU I 45 Cells \\
\hline
\end{tabular}

${ }^{*} P<0.05$ vs. controls.

(0.01 nM) and a higher (100 nM) dose were ineffective (Table II).

\section{RT-PCR of Human Mel $\mathrm{Ia}_{\mathrm{a}}$ and $\mathrm{Mel}_{\mathrm{lb}}$ Melatonin Receptor Transcripts}

The expression of membrane receptors for melatonin in DU 145 prostate cancer cells was evaluated by RT-PCR, utilizing primers specific for $\mathrm{Mel}_{1 \mathrm{a}}$ and $\mathrm{Mel}_{1 \mathrm{~b}}$ cDNAs.

Figure 2 shows that a $\mathrm{Mel}_{1 \mathrm{a}}$-specific cDNA (718 bp) could be amplified and identified by Southern blot in DU 145 cells (Fig. 2, lane 2). The same band was detected in the positive control (human embryonic kidney cell line HEK293, Fig. 2, lane 3). No amplification product was seen in samples in which the reverse transcriptase was omitted (Fig. 2, lane 1). RT-PCR for $\mathrm{Mel}_{1 \mathrm{~b}}$ mRNA did not yield any amplification product, indicating that prostate cancer cells do not seem to express this melatonin membrane receptor, at least when evaluated by RT-PCR.

\section{Melatonin Binding Sites in DU I45 Cells}

Experiments were performed to verify the presence of melatonin binding sites and to clarify their cellular localization. To this purpose, binding experiments were performed on both membrane and nuclear preparations from DU 145 cells, using 2-[125I]iodomelatonin as the ligand. No detectable binding could be observed in membrane preparations. On the contrary, the results obtained from homologous binding curves showed specific 2-[ $\left.{ }^{125} \mathrm{I}\right]$ iodomelatonin binding in nuclear preparations. Computer analysis of the data revealed that in DU 145 cells, 2-[ ${ }^{125}$ I]iodomelatonin interacts with a single class of nuclear binding sites, with a $\mathrm{K}_{\mathrm{d}}$ value of $4.4 \times 10^{-10} \mathrm{M}$ and a $\mathrm{B}_{\max }$ value of $42 \mathrm{fmoles} / \mathrm{mg}$ protein (Fig. 3).

\section{Effects of Melatonin on cAMP Accumulation in DU 145 Cells}

Membrane receptors for melatonin are known to be coupled to the activation of Gi proteins and to a de-
TABLE II. Effects of Melatonin on Forskolin-Induced Stimulation of cAMP Synthesis*

\begin{tabular}{llc}
\hline Treatment & Concentration & cAMP concentration \\
\hline Controls & & $16.6 \pm 3.6$ \\
Forskolin & $5 \mu \mathrm{M}$ & $302.3 \pm 31.8$ \\
Melatonin & $1 \mathrm{nM}$ & $11.3 \pm 5.8$ \\
Forskolin + melatonin & $5 \mu \mathrm{M}+1 \mathrm{nM}$ & $398.2 \pm 37.3$ \\
\hline
\end{tabular}

*Cultures were treated with forskolin and/or melatonin for 15 min. cAMP levels were determined as described in Materials and Methods and are expressed as pmoles/plate. The data are the mean $\pm \mathrm{SE}$ of four experiments, each performed in quadruplicate.

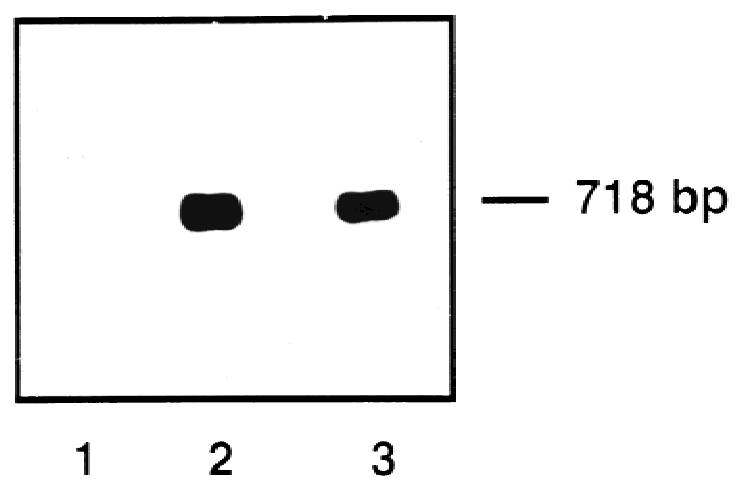

Fig. 2. Autoradiography of RT-PCR products obtained from DU I 45 cells (lane 2) after gel electrophoresis, Southern blotting, and hybridization with a specific ${ }^{32} \mathrm{P}$-labeled oligonucleotide $\mathrm{Mel}_{\mathrm{Ia}}$ probe. No amplification product could be detected in samples in which the reverse transcriptase was omitted (lane I). Lane 3, positive control (human embryonic kidney cell line, HEK293).

crease of intracellular levels of cAMP $[20,21]$. These studies were undertaken to determine whether, in prostate cancer cells, melatonin could modify forskolin-induced accumulation of cAMP. As indicated in Table II, melatonin failed to prevent the stimulation of cAMP synthesis induced by forskolin in DU 145 cells.

\section{DISCUSSION}

The data reported in this paper demonstrate that doses of melatonin, corresponding to the physiological concentrations in blood (nanomolar range), significantly inhibit the growth of the human androgenindependent DU 145 prostate cancer cell line. Moreover, the pineal hormone affects cell cycle distribution, accumulating cells in G0/G1 phase, while decreasing the number of cells in $S$ phase. This indicates that the antiproliferative action of melatonin is not due to a cytotoxic effect on these cells, but rather to a modification of the cell cycle length. In agreement with these observations, we recently reported [9] an anti- 


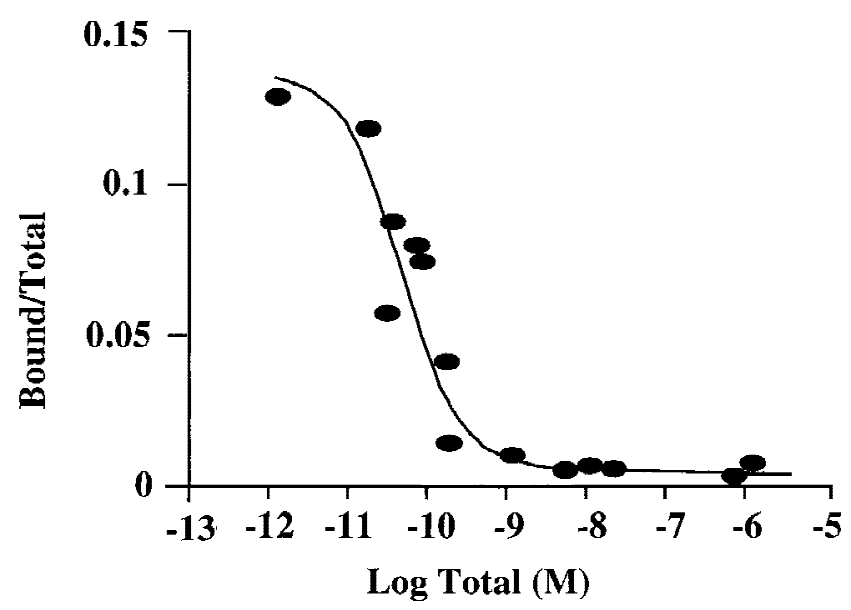

Fig. 3. Specific binding of 2-[125I]melatonin to nuclear preparations from DU 145 cells. The binding assay was performed as described in Materials and Methods. The binding isotherms were analyzed by the LIGAND program, and the binding parameters $\left(B_{\max }\right.$ and $\left.K_{d}\right)$ were determined. One representative curve, out of four binding experiments, is reported.

proliferative action of the indolic hormone on the human androgen-sensitive LNCaP prostate cancer cell line. Thus, melatonin seems to exert a direct cytostatic action on prostate cancer cells, independent of their dependence on testicular steroids.

A direct interaction between melatonin and prostate cancer was previously proposed, although controversial results have been reported. Melatonin has been shown to inhibit the growth of R3327H Dunning prostate adenocarcinoma [22] but to enhance the growth of a transplantable androgen-insensitive prostatic adenocarcinoma in rats [23]. Physiological concentrations of the hormone inhibit ${ }^{3} \mathrm{H}$-thymidine incorporation in androgen-sensitive LNCaP prostate cancer cells [24]; in androgen-insensitive PC3 prostate cancer cells, melatonin differently affects ${ }^{3} \mathrm{H}$-thymidine incorporation according to cell density [25], stimulating it at low cell density and attenuating it in high-density cultures [25]. At present, the reasons for the partial discrepancy between these observations and the data reported in our paper are unclear. However, they might be accounted for by the different experimental conditions adopted (e.g., cell lines, cell culture conditions).

On the other hand, consistent with the data here reported, a direct oncostatic action of melatonin has been demonstrated in a variety of tumor cells other than prostate cancer. Physiological, but nor subphysiological or pharmacological, concentrations of melatonin have been shown to exert a direct antiproliferative effect on human estrogen-responsive MCF-7 breast cancer cells $[7,26,27]$. The pineal hormone also inhibits the growth of the human ovarian adenocarcinoma BG-1 cell line [28], of human neuroblastoma SK-N-SH cells [29], of murine colon 38 adenocarcinoma cells [30], and of rat melanoma [31] or pheocromocitoma [32] cells.

It is interesting that, in breast cancer, melatonin is able to exert its antimitogenic action on estrogendependent, but not on hormone-unresponsive, cells. In estrogen-dependent breast cancer cells, the pineal hormone appears to act mainly by interfering with the estrogen response system [33-35]. In contrast, according to our observations, melatonin can inhibit the growth of both androgen-dependent [9] and androgen-independent (data here reported) prostate cancer cells. Experiments are in progress in our laboratory to clarify whether the pathways through which the hormone exerts its cytostatic activity might be similar in the two different cell models.

In spite of the several reports supporting a direct cytostatic effect of melatonin on cancer cells, the signal transduction pathway mediating this activity is still unknown. In this paper, we have shown that, in DU 145 cells, $\mathrm{Mel}_{1 \mathrm{a}}$ membrane receptors are expressed at the mRNA level; however, by radioreceptor assays, no binding sites for ${ }^{125} \mathrm{I}$-melatonin could be detected in membrane preparations. We concluded that the level of translation of $\mathrm{Mel}_{1 \mathrm{a}}$ mRNA was too low to possibly mediate a physiological effect. This conclusion is further supported by the observation that melatonin does not affect forskolin-induced cAMP accumulation. It is actually well-known that ligand-induced activation of membrane $\mathrm{Mel}_{1 \mathrm{a}}$ receptors is followed by decreased intracellular cAMP formation [20,21]. On the other hand, we have shown that binding sites for ${ }^{125} \mathrm{I}$ melatonin can be detected in the nuclear fraction of DU 145 cells, suggesting that the oncostatic activity of this hormone might be mediated, at least partially, by receptors localized in the nucleus. We recently reported similar results on androgen-sensitive LNCaP prostate cancer cells [9]. The hypothesis of a nuclear site of action of melatonin is supported by previous observations made in breast cancer cells. First, little to no melatonin binding has been found in MCF-7 breast cancer cell membranes [36]. Second, melatonin has been reported to inhibit the binding of the estradiolestrogen receptor complex to the estrogen response element in nuclear extracts of MCF-7 cells [35]. According to the authors, these observations suggest the presence, in nuclear extracts, of a receptor for melatonin, which is able to interfere with the binding to DNA of the activated estrogen receptor. In this context, it is important to note that physiological actions of melatonin, other than the oncostatic one, have been proposed to be nuclear receptor-mediated $[37,38]$.

Although increasing attention has recently been devoted to the "putative" nuclear receptor for melatonin, its identity remains unknown. Melatonin binding to 
the orphan nuclear receptor $\mathrm{RZR} / \mathrm{ROR} \alpha$ has been demonstrated by transient transfection assays in Drosophila cells [39-41]. RZR/ROR $\alpha$ receptors have been suggested to mediate the effects of melatonin in the control of cell growth and differentiation. However, the possibility that this transcription factor might be the nuclear receptor for melatonin is still a matter of debate $[42,43]$. Calmodulin has been suggested as another potential candidate receptor for melatonin [35]. It was previously demonstrated that calmodulin may facilitate the binding of activated steroid receptors to their specific DNA response element [35,44]. On the other hand, the pineal hormone has been shown to bind to calmodulin in a $\mathrm{Ca}^{++}$-dependent fashion, resulting in inhibition of calmodulin $[45,46]$.

In conclusion, the data here reported indicate that melatonin exerts cytostatic activity on human androgen-independent DU 145 prostate cancer cells, by affecting cell cycle progression. This activity seems to be nuclear, but not membrane, receptor-mediated. Additional studies are needed to identify the receptor involved in the oncostatic property of melatonin.

Our results, together with previous reports on different human neoplasms, seem to suggest that melatonin might be considered as an effective cytostatic agent, either alone or in combination with standard anticancer treatments. This hypothesis is further supported by the well-known immunostimulatory and antioxidant properties of the hormone.

\section{REFERENCES}

1. Brzezinski A. Melatonin in humans. N Engl J Med 1997;336:186195.

2. Ronco AL, Halberg F. The pineal gland and cancer. Anticancer Res 1996;16:2033-2040.

3. Sanchez-Barcelo EJ, Mediavilla MD, Cos S. Effects of melatonin on experimental mammary cancer development. In: Webb SM, Puig-Domingo M, Moller M, Pevet $\mathrm{P}$, editors. Pineal update: from molecular mechanisms to clinical implications. New York: PJD Publications, Ltd.; 1997. p 361-368.

4. Tamarkin L, Danforth D, Lichter A, DeMoss E, Cohen M, Chabner B, Lippman M. Decreased nocturnal plasma melatonin peaks in patients with estrogen receptor positive breast cancer. Science 1982;216:1003-1005.

5. Bartsch C, Bartsch H, Schmidt A, Ilg S, Bichler KH, Flutcher SH. Melatonin and 6-sulfatoxymelatonin circadian rhythms in serum and urine of primary prostate cancer patients: evidence for reduced pineal activity and relevance of urinary determinations. Clin Chim Acta 1992;209:153-167.

6. Bartsch C, Bartsch H, Karenovics A, Franz G, Peiker G, Mecke D. Nocturnal urinary 6-sulfatoxymelatonin excretion is decreased in primary breast cancer patients compared to agematched controls and shows negative correlation with tumorsize. J Pineal Res 1997;23:53-58.

7. Hill SM, Blask DE. Effects of the pineal hormone melatonin on the proliferation and morphological characteristics of human breast cancer cells (MCF-7) in culture. Cancer Res 1988;48:61216126.
8. Baldwin WS, Barrett JC. Melatonin: receptor-mediated events that may affect breast and other steroid hormone-dependent cancer. Mol Carcinog 1998;21:149-155.

9. Moretti RM, Montagnani Marelli M, Maggi R, Dondi D, Motta M, Limonta P. Antiproliferative action of melatonin on human prostate cancer LNCaP cells. Oncol Rep 2000;7:347-351.

10. Gittes RF. Carcinoma of the prostate. N Engl J Med 1991;324: 236-245.

11. Leewansangton S, Crawford ED. Maximal androgen withdrawal for prostate cancer therapy: current status and future potential. Endocr Rel Cancer 1998;5:325-339.

12. Stone KR, Mickey DD, Wunderli H, Mickey GH, Paulson DF. Isolation of a human prostate carcinoma cell line (DU 145). Int J Cancer 1978;21:274-281.

13. Soma MR, Baetta R, De Renzis MR, Mazzini G, Davegna C, Magrassi L, Butti G, Pezzotta S, Paoletti R, Fumagalli R. In vivo enhanced antitumor activity of carmustine [N, $\mathrm{N}^{\prime}$-bis $(2-$ chloroethyl)-N-nitrosourea] by simvastatin. Cancer Res 1995;55: 597-602.

14. Conway S, Drew JE, Canning SJ, Barrett P, Jockers R, Strosberg AD, Guardiola-Lemaitre B, Delagrange P, Morgan PJ. Identification of $\mathrm{Mel}_{1 \mathrm{a}}$ melatonin receptors in the human embryonic kidney cell line HEK293: evidence of G protein-coupled melatonin receptors which do not mediate the inhibition of stimulated cyclic AMP levels. FEBS Lett 1997;407:121-126.

15. Blum M, McEwen B, Roberts JL. Transcriptional analysis of the tyrosine hydroxylase gene expression in the tuberoinfundibular dopaminergic neurons of the rat arcuate nucleus after estrogen treatment. J Biol Chem 1987;262:817-821.

16. Rovati GE, Rodbard D, Munson P. Optimization of experimental design for ligand binding studies: improved estimation of affinity and binding capacity. Pharmacol Res 1989;21:71-72.

17. Munson PJ, Rodbard D. LIGAND: a versatile computerized approach for characterization of ligand-binding systems. Anal Biochem 1980;107:220-239.

18. Bradford MM. A rapid and sensitive method for the quantitation of microgram quantities of protein utilizing the principle of protein-dye binding. Anal Biochem 1976;72:248-254.

19. Dunnett CW. A multiple comparison procedure for comparing several treatments with a control. J Am Stat Assoc 1955;50:10961121.

20. Reppert SM, Weaver DR, Ebisawa T. Cloning and characterization of a mammalian melatonin receptor that mediates reproductive and circadian responses. Neuron 1994;13:1177-1185.

21. Godson C, Reppert SM. The $\mathrm{Mel}_{1 \mathrm{a}}$ melatonin receptor is coupled to parallel signal transduction pathways. Endocrinology 1997; 138:397-401.

22. Philo R, Berkowitz AS. Inhibition of Dunning tumor growth by melatonin. J Urol 1988;139:1099-1102.

23. Buzzell GR. Studies on the effects of the pineal hormone melatonin on an androgen-insensitive rat prostatic adenocarcinoma, the Dunning R 3327 HIF tumor. J Neural Transm 1988;72:131140.

24. Lupowitz Z, Zisapel N. Hormonal interactions in human prostate tumor LNCaP cells. J Steroid Biochem Mol Biol 1999;68:8388.

25. Gilad E, Laufer M, Matzkin H, Zisapel N. Melatonin receptors in PC3 human prostate tumor cells. J Pineal Res 1999;26:211-220.

26. Cos S, Fernandez F, Sanchez-Barcelo EJ. Melatonin inhibits DNA synthesis in MCF-7 human breast cancer cells in vitro. Life Sci 1996;58:2447-2453.

27. Hill SM, Spriggs LL, Simon MA, Muraoka H, Blask DE. The growth inhibitory action of melatonin on human breast cancer cells is linked to the estrogen response system. Cancer Lett 1992; 64:249-256. 
28. Petranka J, Baldwin W, Biermann J, Jayadev S, Barrett JC, Murphy $\mathrm{E}$. The oncostatic action of melatonin in an ovarian carcinoma cell line. J Pineal Res 1999;26:129-136.

29. Cos S, Verduga R, Fernandez-Viadero CF, Megias M, Crespo D. Effects of melatonin on the proliferation and differentiation of human neuroblastoma cells in culture. Neurosci Lett 1996;216: $113-116$.

30. Karasek M, Winczyk K, Kunert-Radek J, Wiesenberg I, Pawlikowski M. Antiproliferative effects of melatonin and CGP 52608 on the murine colon 38 adenocarcinoma in vitro and in vivo. Neuroendocr Lett 1998;19:71-78.

31. Slominski A, Pruski D. Melatonin inhibits proliferation and melanogenesis in rodent melanoma cells. Exp Cell Res 1993;206: 189-194.

32. Roth JA, Rabin R, Agnello K. Melatonin suppression of PC12 cell growth and death. Brain Res 1997;68:63-70.

33. Molis TM, Spriggs LL, Jupiter Y, Hill SM. Melatonin modulation of estrogen-regulated proteins, growth factors, and protooncogenes in human breast cancer. J Pineal Res 1995;18:93-103.

34. Ram PT, Kiefer T, Silverman M, Song Y, Brown GM, Hill SM. Estrogen receptor transactivation in MCF-7 breast cancer cells by melatonin and growth factors. Mol Cell Endocrinol 1998;141: 53-64.

35. Garcia Rato A, Garcia Pedrero J, Martinza MA, Del Rio B, Lazo $\mathrm{S}$, Ramos S. Melatonin blocks the activation of estrogen receptor for DNA binding. FASEB J 1999;13:857-868.

36. Stankov B, Lucini V, Scaglione F, Cozzi B, Righi M, Canti G, Demartini G, Fraschini F. 2-[ $\left.{ }^{125} \mathrm{I}\right]$ Iodomelatonin binding in normal and neoplastic tissues. In: Fraschini F, Reiter J, editors. Role of melatonin and pineal peptides in neuroimmunomodulation. New York: Plenum Press; 1991. p 117-125.

37. Garcia-Maurino S, Gonzales-Haba MG, Calvo JR, Rafii-El-Idrissi M, Sanchez-Margalet V, Goberna R, Guerrero JM. Melatonin enhances IL-2, IL-6, and IFN $\gamma$ production by human circulating $\mathrm{CD}^{+}$cells. J Immunol 1997;159:574-581.

38. Rafii-El-Idrissi M, Calvo JR, Harmouch A, Garcia-Maurino S,
Guerrero JM. Specific binding of melatonin by purified cell nuclei from spleen and thymus of the rat. J Immunol 1998;86:190197.

39. Becker-André M, Wiesenberg I, Schaeren-Wiemers N, André E, Missbach M, Saurat J-H, Carlberg C. Pineal gland hormone melatonin binds and activates an orphan of the nuclear receptor superfamily. J Biol Chem 1994;269:28531-28534.

40. Wiesenberg I, Missbach M, Kahlen J-P, Schräder M, Carlberg C. Transcriptional activation of the nuclear receptor RZR $\alpha$ by the pineal hormone melatonin and identification of CGP 52608 as a synthetic ligand. Nucleic Acids Res 1995;23:327-333.

41. Wiesenberg I, Missbach M, Carlberg C. The potential role of the transcription factor RZR/ROR as a mediator of nuclear melatonin signaling. Restorative Neurol Neurosci 1998;12:143-150.

42. Becker-André M, Schaeren-Wiemers N, André E. Correction to the article "Becker-André $\mathrm{M}$, Wiesenberg I, Schaeren-Wiemers N, André E, Missbach M, Saurat J-H, Carlberg C: Pineal gland hormone melatonin binds and activates an orphan of the nuclear receptor superfamily. J Biol Chem 1994;269:2853128534." J Biol Chem 1997;272:16707.

43. Wiesenberg I, Missbach M, Saurat J-H, Carlberg C. Addition to the article "Becker-André M, Wiesenberg I, Schaeren-Wiemers N, André E, Missbach M, Saurat J-H, Carlberg C: Pineal gland hormone melatonin binds and activates an orphan of the nuclear receptor superfamily. J Biol Chem 1994;269:2853128534." J Biol Chem 1997;272:16707.

44. Bouhoute A, Leclerq G. Modulation of estradiol and DNA binding to estrogen receptor upon association with calmodulin. Biochem Biophys Res Commun 1995;208:748-755.

45. Benitez-King G, Huerto-Delgadillo L, Anton-Tay F. Melatonin modifies calmodulin levels in MDCK and NIE-115 cell lines and inhibits phosphodiesterase activity in vitro. Brain Res 1991;557: 289-292.

46. Romero MP, Garcia-Pergadena A, Guerrero JM, Osuna C. Membrane-bound calmodulin in X. laevis oocytes as a novel binding site for melatonin. FASEB J 1998;12:1401-1408. 